\title{
Effect of post-grazing sward height on grass production and performance of four beef heifer genotypes
}

\section{W Minchin, M McGee}

Teagasc Grange Beef Research Centre, Dunsany, Ireland

Email:william.minchin@teagasc.ie

Introduction Feed is the largest variable cost on beef farms and efficiently managed grazed grass is the cheapest feedstuff available (Finneran et al., 2009). Consequently, maximising animal performance from grazed grass should be the basis of sustainable beef systems. There is evidence that grazing to a lower residual sward height $(4 \mathrm{~cm} \mathrm{vs.} 6 \mathrm{~cm}) \mathrm{improves}$ the yield and subsequent quality of swards (Fulkerson and Donaghy, 2001). However, research has shown mixed results of this practice on performance of the dairy cow (Maher et al., 2003; Humphreys, 2009). Most research examining postgrazing sward height in beef cattle is confounded with stocking rate. Consequently, there is a deficit in information on this grazing practice for beef cattle, especially for late-maturing continental crossbreds, the predominant breed types in Ireland. The objective of this experiment was to evaluate the effects of two contrasting grassland management systems on grass production and performance of four late-maturing crossbred breeding heifer genotypes.

Material and methods One hundred and thirty-six heifers (10-24 months old) comprising of 4 genotypes: Limousin $\times$ Holstein-Friesian (LF), Limousin $\times$ Simmental (LS), Charolais $\times$ Limousin $(C L)$, and Charolais $\times$ Simmental $($ CS $)$ were blocked by genotype, live weight, body condition score (BCS), age and suckler beef value (economic breeding index), and from within block, randomly assigned to one of two grassland management systems: grazing to a post-grazing sward height of either 4.0 or $6.0 \mathrm{~cm}$. There were two replications of each grazing system resulting in four groups of 34 animals on 40 ha. The stocking rate was $2.5 \mathrm{LU} / \mathrm{ha}$ equivalent to $195 \mathrm{~kg}$ of organic nitrogen/ha for each grazing system. The experiment was undertaken from early March to early November during which, animals were rotationally grazed on predominantly perennial ryegrass swards. Fresh herbage was allocated to each system once the target post-grazing residual height was achieved. Forty five percent of the land area of each system was conserved as grass silage, harvested on $4^{\text {th }}$ June. Herbage surplus to grazing requirements (i.e. when farm cover exceeded requirements) was removed from the rotation by harvesting relevant paddocks for silage. Heifers were bred (May-July) to Blonde d'Aquitaine sires. At the end of the grazing season, they were housed and offered grass silage ad libitum. Animal live weight, BCS and ultrasonic fat and muscle depths were measured. To permit adjustments in gut fill, final live weight was obtained 7 days post-housing. Grassland measurements included, pre and post-grazing compressed sward heights (rising plate meter), herbage mass ( $>4$ $\mathrm{cm}$ - lawnmower cuts), sward density, herbage production, farm cover and grazing days. Data were statistically analysed using PROC Mixed in SAS.

Results Pre-grazing sward height and herbage mass did not differ $(\mathrm{P}>0.05)$ between grazing systems with mean values of $10.4 \mathrm{~cm}$ and $1920 \mathrm{~kg} \mathrm{DM} / \mathrm{ha}$, respectively. By design, post-grazing sward height (4.4 vs. $5.6 \mathrm{~cm})$ and herbage mass (484 vs. $920 \mathrm{~kg} \mathrm{DM} / \mathrm{ha})$ was lower $(\mathrm{P}<0.001)$ for the $4 \mathrm{~cm}$ than the $6 \mathrm{~cm}$ system. An additional 20 tonnes DM of surplus grazed grass (26 v. $6 \mathrm{t} \mathrm{DM}$ ) was removed (as silage) from the $4 \mathrm{~cm}$ system compared to the $6 \mathrm{~cm}$ system. There was no difference $(\mathrm{P}>0.05)$ in animal performance between the two grazing systems (Table 1$)$. There were no genotype $\times$ grazing system interactions for all variables measured. Initial live weight was lower for LF than LS and CL, who in turn, were lower than CS $(\mathrm{P}<0.05)$. Final live weight was greater $(\mathrm{P}<0.05)$ for $\mathrm{CS}$ than $\mathrm{CL}$ and $\mathrm{LF}$, with $\mathrm{LS}$ being intermediate $(\mathrm{P}>0.05)$ to $\mathrm{CL}$ and CS, but live weight gain did not differ between the genotypes. Initial BCS was lower for LF than LS, CL and CS $(\mathrm{P}<0.05)$, however final BCS did not differ $(\mathrm{P}>0.05)$ between the genotypes. BCS gain was greater $(\mathrm{P}<0.001)$ for $\mathrm{LF}$ than LS and CS with CL being intermediate.

Table 1 Performance of four heifer genotypes on two grazing management systems

\begin{tabular}{|c|c|c|c|c|c|c|c|c|c|c|}
\hline & \multicolumn{4}{|c|}{ Genotype } & & & \multicolumn{4}{|c|}{ Grazing system } \\
\hline & LF & LS & $\mathrm{CL}$ & $\mathrm{CS}$ & SEM & Sig. & $4 \mathrm{~cm}$ & $6 \mathrm{~cm}$ & SEM & Sig. \\
\hline Initial live weight (kg) & $419^{\mathrm{a}}$ & $453^{b}$ & $451^{b}$ & $470^{\mathrm{c}}$ & 10.7 & $*$ & 449 & 447 & 6.8 & $\mathrm{NS}$ \\
\hline Final live weight $(\mathrm{kg})$ & $569^{\mathrm{a}}$ & $595^{\mathrm{bc}}$ & $585^{\mathrm{ab}}$ & $612^{\mathrm{c}}$ & 10.3 & * & 588 & 594 & 9.4 & NS \\
\hline Daily live weight gain $(\mathrm{kg})$ & 0.68 & 0.65 & 0.61 & 0.65 & 0.034 & NS & 0.63 & 0.67 & 0.037 & NS \\
\hline Initial body condition score $(0-5)$ & $3.04^{\mathrm{a}}$ & $3.18^{\mathrm{b}}$ & $3.16^{\mathrm{b}}$ & $3.23^{\mathrm{b}}$ & 0.043 & $*$ & 3.15 & 3.16 & 0.027 & NS \\
\hline Final body condition score $(0-5)$ & 3.26 & 3.20 & 3.26 & 3.22 & 0.034 & NS & 3.22 & 3.25 & 0.022 & NS \\
\hline Body condition score change $(0-5)$ & $0.22^{\mathrm{a}}$ & $0.02^{\mathrm{b}}$ & $0.11^{\mathrm{ab}}$ & $-0.01^{\mathrm{b}}$ & 0.041 & $* * *$ & 0.07 & 0.10 & 0.026 & NS \\
\hline
\end{tabular}

Conclusion Potential exists to increase herbage production by grazing to a lower post-grazing residual height without sacrificing animal performance.

\section{References}

Finneran, E., Crosson, P., Wallace, M., O’Kiely, P., Shalloo, L. and Forristal, D. (2009). Agricultural Research Forum, 67. Fulkerson, W.J., Donaghy, D.J. (2001). Australian Journal of Experimental Agriculture, 41, 261-275.

Humphreys, J. (2009). Agricultural Research Forum, 99.

Maher, J., Stakelum, G., Rath, M. (2003). Irish Journal of Agricultural Research, 42, 229-241. 